\title{
HOW ADAT LAW BREAKS THE CYCLE OF VENGEANCE: THE EPKERET TRADITION IN SOUTHERN BURU
}

\author{
Ari Siswanto* dan Leo CM. Teslatu** \\ Faculty of Law, Universitas Kristen Satya Wacana, Salatiga \\ J1. Diponegoro 52-60 Salatiga 50711
}

\begin{abstract}
This study was conducted on epkeret practice as an adat institution to resolve the conflict in South Buru. Specifically, the examined problems are how epkeret contributes to resolving inter-family conflicts and how the parties perceive epkeret. This study aims to identify the potential of epkeret as a customary dispute resolution. The research, which was mainly conducted using interview method, reveals that epkeret played an important role in preventing the cycle of violence in society. Another result obtained is that parties associated with epkeret have a positive perception of this adat institution.
\end{abstract}

Keywords: lex talionis, adat institution, conflict resolution.

\section{Intisari}

Penelitian ini dilakukan terhadap praktik epkeret sebagi pranata adat untuk menyelesaikan konflik di Buru Selatan. Secara lebih spesifik masalah yang diteliti adalah bagaimana kontribusi epkeret dalam menyelesaikan konflik antar-keluarga dan bagaimana pihak-pihak yang terkait mempersepsikan epkeret. Penelitian ini bertujuan mengidentifikasi potensi epkeret sebagai salah satu cara penyelesaian sengketa secara adat. Penelitian yang terutama dilakukan melalui metode wawancara ini mengungkapkan bahwa epkeret memainkan peran penting untuk mencegah siklus kekerasan di dalam masyarakat. Hasil lain yang diperoleh adalah bahwa pihak-pihak yang terkait dengan epkeret memiliki persepsi positif terhadap pranata adat ini.

Kata kunci: lex talionis, pranata adat, penyelesaian konflik.

\section{Pokok Muatan}

A. Research Background 360

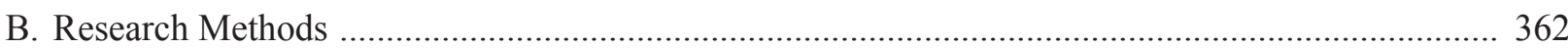

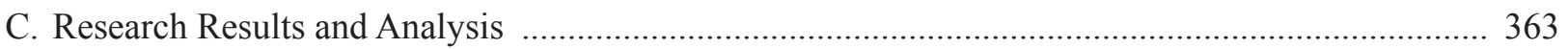

1. Contribution Epkeret to the restoration of relationship between the family of the victim and that of the perpetrator following a murder caseas a mechanism to break the cycle of violence after the murder cases in Southern Buru

2. Perception of the people who are directly affected by the implementation of epkeret tradition

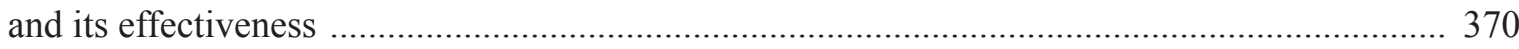

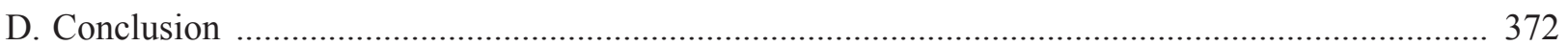

Corresponding address: arie.siswanto@staff.uksw.edu.

Corresponding address: teslatumeno@gmail.com. 


\section{A. Research Background}

Conflicts of interests that develop into disputes are quite usual and could always be found in every society. If it left unresolved, disputes will remain among the conflicting parties or, even worse, become more extensive and involve more and more parties. This condition is certainly not desired by the community because of its potential to disrupt the order of the community. Therefore, it is natural that every community develops its dispute resolution mechanism.

Among modern societies, courts are the common institution for dispute settlement. Through courts, a dispute will be examined using formal legal norms as the standard. The judges who preside in a case will apply these norms and determine which disputing party is right and which is wrong. Generally, the courts will end up in zero-sum solutions, because the applied standard is a legal norm that tends to be inflexible and rigid. Thus, the resolution of a dispute in the court often places the disputing parties in fairly opposite sides, where one party wins while the other loses.

In social terms, the settlement of conflict through court adjudication does not necessarily make the dispute completely resolved. The zerosum nature of the court ruling sometimes creates a disturbed relationship between the disputing parties, which further makes it almost impossible for them to establish a good relationship in the future. Nevertheless, for modern society, the condition has generally been considered and realized as a consequence that must be accepted when the parties choose the court settlement as a method of dispute resolution.

In traditional communities, however, the situation may be different. Traditional societies are generally characterized by relationships that emphasize togetherness, so the need to preserve the integrity of society is also considered as quite important since it reflects what Putnam termed as "bonding social capital." Thus, it is plausible that the dispute resolution mechanism developed by the traditional community is perceived as more important than the formal court mechanism. In some communities, even the act of settling the dispute in the court is considered as a taboo and harmful to long-term interpersonal relationships.

In addition to disputes on civil matters, the public order can also be disrupted by criminal acts. However, unlike settlements of disputes over civil matters, criminal court examination is not an option. In modern countries, criminal cases usually reside in the domain of the criminal justice authority, which is a representation of the state authority. In this context, it is the state's responsibility to create and develop order in society, including through the enforcement of criminal law through the courts.

In a normative sense, when a criminal case is examined in the court, and the defendant is convicted and sentenced, the criminal justice process is deemed to be completed. However, it does not necessarily mean that the case is completely resolved sociologically. Among those who still have faith in retributive justice (lex talionis), criminal prosecution of criminals does not necessarily make the victims of crime and his/her family accept the court's decision and consider the issue to be settled. Under the lex talionis principle of justice, there must be like for like in some way, in the case of punishment. ${ }^{2}$ Therefore, when it comes to murder cases that claim lives, the anger that exists in the victim's family does not automatically vanish after the perpetrators of the crime have been sentenced. Instead, "life for life" retaliation still has a great chance of taking place to fulfil the "lust for vengeance". ${ }^{3}$ Thus, especially in most traditional communities, state law enforcement has not guaranteed the restoration of public order that had been disturbed by criminal offenses. Even after the state law is enforced, there 
is always an opportunity for a cycle of violence to arise when the clan (family) of the victim and that of the perpetrator take revenge on each other. Therefore, internal dispute resolution mechanisms generally remain a necessity for traditional communities despite the existing formal dispute resolution mechanism through the courts.

In the context of Indonesia, dispute resolution mechanism developed among traditional communities could function well, mostly among those who strongly embrace traditional values and prioritize common interests over individual interests. This important point drives the idea that traditional dispute resolution institutions should be studied more intensely to develop better conflict resolution mechanism to address social conflicts. ${ }^{4}$

One of the types of internal dispute resolution mechanism that is intended to preserve the integrity of the community is the epkeret tradition practiced among the people of Southern Buru Island in Maluku Province, Indonesia. This traditional (adat) institution developed based on local wisdom and is applied in murder cases that are potentially damaging to inter-group relations in the community. In traditional communities that are still believe in lex talionis, murder can lead to an endless cycle of violence when the family of the victims retaliate against the family of the perpetrator, who then also retaliate back to the family members of the victim. It is in such a context that the people of the Southern Buru Island develop the epkeret tradition as one of the mechanisms for breaking the chain of violence that can be triggered by murder.

As a method of breaking the cycle of violence that may arise from a murder case, the epkeret is practiced through a procedure in which the family of the murderer assigns one of his family members to the victim's family as a "replacement" for the murdered victim. Through the adat ceremony, this "replacement" will be transferred into the victim's family and will since then be part of the victim's family.
This research is intended to describe the epkeret tradition as a method to bring peace and order among the people of Southern Buru Island, especially in the aftermath murder cases. There are two main issues to be discussed in this paper: (a) how the epkeret institution works as a mechanism to break the cycle of violence in Southern Buru society; and (b) how the epkeret institution is perceived by those who are directly affected by its implementation. The second issue is important in determining the effectiveness of epkeret in breaking the cycle of violence as a result of murder inter-clan murder casen.

It should be underlined that currently there is no detailed study of epkeret as an adat institution. Therefore, this study is more exploratory in nature. The study was conducted by applying empirical research methods that utilized primary data from field research in Districts of Leksula and Fena Fafan, South Buru Regency, focusing on two murder cases, which were followed by the epkeret implementation, which occurred in 1982 and 2015 respectively. The data in this study primarily are the parties that were involved in the implementation of epkeret, including particular clan whose member committed murder, and thus, bear the responsibility to provide a "replacement", a clan whose members were killed and subsequently received "replacements," as well as those who were the "replacement" in the epkeret tradition. Furthermore, since the epkeret tradition was triggered by a murder case, which essentially falls under national criminal law domain, the data are also drawn from the relevant criminal law enforcement officers as informants.

Based on the description above, this study attempted to address the following research questions:

(1) How does the epkeret tradition work as a mechanism to break the cycle of violence in Southern Buru society?

(2) How do people who are directly affected by the implementation of 
epkeret perceive the epkeret tradition and its effectiveness?

\section{B. Research Methods}

Mengesha et al. state that research methodology is basically a coherent set of rules and procedures that are used to investigate a problem, which includes the tools and techniques of data gathering and analysis. ${ }^{5}$ This research was conducted in four villages located in two different districts, namely Siwatlahin Village, Waelo Village and Waekatin Village (both in Fena Fafan District) and Leksula Village in Leksula District, Southern Buru Island area, South Buru Regency, Maluku Province in Indonesia, in which practice of epkeret was recently identified. This study was focused on two occasions when the epkeret tradition was implemented in that area in 1982 and in 2015.

The focus of this research is primarily a social phenomenon that cannot be measured by quantifications. In such case, Therefore, this research used a qualitative approach to seek elucidation on the two research questions. The research method employed in this research is the empirical one, which is 'the systematic collection of information ("data") and its analysis according to some generally accepted method' . ${ }^{6}$

The main instrument used in data collection is interview with the prominent members of the indigenous community, as well as with those who are directly involved in the implementation of epkeret tradition, such as the family of the murder victims, the family of the perpetrators, the perpetrator of murder himself, and the member of the perpetrator's family who was appointed to "replace" the victim position.

Furthermore, two data gathering methods applied in this study to obtain the required data, namely:

\section{a. Key Informant Interview}

Key informantinterview was conducted with knowledgeable people who were either able to provide valid data concerning the existence of epkeret tradition or having adequate information on the implementation of epkeret tradition in the two cases studied and its aftermath. The main informants that were covered by this category were:

- Mr. Simon Lesnusa, the perpetrator of fah rahat (murder);

- Mr. Samuel Liligoli, previously also known as Samuel Lesnusa, the brother of Simon Lesnusa, the member of Lesnusa family who was appointed to replace the position of Philipus Liligoli, the victim of murder perpetrated by Simon Lesnusa;

- Mrs. Koce Solissa, the biological mother of Ribka Solissa, the girl who was "established" as the replacement for Yati Nacikit, the murder victim;

\section{b. Observation}

The observation was used as the data collection instrument to examine the validity of information obtained from interviews. The observation was focused on the general situation following the implementation of epkeret tradition, particularly, the relationship between families that were involved in the fah rahat (murder) cases.

Based on the research questions, the relevant information gathered from this research were then analyzed to answer the research questions comprehensively. This study employed a descriptive approach in interpreting and analyzing research data. It means that the data collected were refined and filtered to achieve the stated research purposes.

Abebe Demewoz Mengesha et al., "Indigenous Conflict Resolution Mechanisms among the Kembata Society", American Journal of Educational Research, 2015, Vol. 3, No. 2, pp.225-242.

Frans L. Leeuw \& Hans Schmeets, Empirical Legal Research A Guidance Book for Lawyers, Legislators and Regulators, Edward Elgar Publishing, Cheltenham, 2016, p. 10. 


\section{Research Results and Analysis}

The analysis divided into two parts that reflect the addressed two research questions. A more general description concerning the practice of epkeret will firstly be presented to get a comprehensive view of the analysis before discussing the main issues addressed in the research questions above.

Among the people of Southern Buru, KaiWait relationship is an important foundation for the communal life. Kai-Wait is basically the belief that all native clans are related and bonded as brothers and sisters. Therefore, disputes among them are required to be resolved by customary law mechanisms that strongly prioritize the integrity of family relationships. It is on this foundation that several types of amicable dispute settlement, including epkeret, developed..

Moreover, epkeret is basically a practice particular to murder cases, in which the clan of the perpetrator provides a person from among them to "replace" the victim's position among his/her family. This replacement is regarded as necessary to restore the order of the community that was hindered by the murderous act that inflicted injury on the side of the victim's family.

However, the concept of "replacement" in epkeret is quite different from the concept of "replacement" in lex talionis. Under lex talionis, the nature of the countermeasure is retaliatory, while in epkeret, the countermeasure is compensatory. xxxxxUnder the lex talionis rule, vengeance as a counter-measure against the previous injury is indispensable, as Robert Solomon once said that vengeance is the emotion of "getting even", putting the world back in balance. ${ }^{7}$ Thus, in lex talionis, "replacement" means taking away something from the perpetrator of a crime to correct the imbalance. Quite differently, in epkeret, the person who is appointed as the "replacement" of a murder victim is required to continue the life of the victim among the victim's family, instead of taken away by being killed, as a compensation for the death of the victim.
In murder cases, epkeret is the primary method to provide compensation for the family of the victim. Furthermore, if there is nobody in the perpetrator's family qualifies as a "replacement", the rahe nefu will apply. Rahe nefu is xxxxa dispute settlement practice following a murder case, in which the family of the perpetrator provide a tract of land to compensate the victim's family injury. However, rahe nefu will usually not be sought if it is possible to apply epkeret.

For example, if the perpetrator's family do not have any family members of the same gender as the murdered victim to be appointed as a "replacement", customary deliberations will be made to enable the perpetrator's family to provide a tract of land to be handed over to the victim's family. In such case, the land is acceptable as a substitute for the human life according to their belief that human was originated from soil and that land is the source of life for a human. Thus, in this case, to some degree, there is flexibility in resolving murder cases among the community. In a situation where the family of the perpetrator could not appoint a replacement as required by the family of the victim, adat norms make it possible for the family of the perpetrator to provide a tract of land as the compensation. This substitution is possible because according to the traditional values of the community, land and human life are closely related, since human is believed to originate from the soil, and that soil will preserve human life through the crops produced. But still, in murder cases, when it comes to compensation, epkeret is more favorable than rahe nefu. The reason for this is that in epkeret, the replacement for the victim's family is a person, and this is regarded as a practice that may bring stronger familial ties than rahe nefu in which a tract of land is provided as the compensation.

As suggested above, epkeret is a component of dispute settlement, particularly those related to murder cases, through the taking of an oath (esmake). There is no accurate record as to when 
the practice of epkeret began to be adopted among the people of Southern Buru. However, there is a widely accepted belief that originally, epkeret was not applied specifically in murder cases. Literally, the term epkeret is derived from the word epak ('approaching') and keret ('to establish'). This term refers to the practice in which a person is 'established' or appointed for a specific common interest. In the beginning, the appointment of a person was done in the interest of maintaining the existence of Buru Island's native clans who were vulnerable to attacks by outsiders. At that time, the original clans of Buru Island agreed to appoint one person from each clan to collectively defend Buru Island from outside threats. This arrangement was agreed upon in the past to remind the clans of Buru Island that they were one big family that need to share the responsibility of defending their island. Thus, representativeness was adopted as a principle to uphold the unity of the clans. The people who were 'established' as warriors by each clan were commonly referred to as 'Kapitan'. Therefore, the epkeret practice was originally performed when a qualified clan member was appointed as a 'Kapitan' to safeguard the common interests of the whole community in the island of Buru.

As times goes by, the original notion behind epkeret practice has shifted in such a way as to include the situation when someone is appointed to serve a more specific purpose, i.e. to replace a person killed in a murder case (fah rahat). Epkeret fundamentally underwent a change of meaning from voluntary institution to institution that reflects compensatory, if not punitive, characteristic. Originally epkeret was a voluntary institution since the appointment of a person as a kapitan was based solely on the common interests of the whole society, which is the protection and security of all Buru Island inhabitants. For example, when other people from outside of the island invaded Buru Island and threaten the common security of the people or even their very existence, the kapitans would represent their respective clans to cooperate with other clans and stood up together to confront the threat.
However, subsequently, epkeret has been linked to murder cases (fah rahat), and the appointment of a person (from the perpetrator's clan) to replace the position of the murdered person reflects more punitive and compensatory nature according to customary law.

As one component of dispute settlement within the realm of customary law institutions, epkeret has a specific nature. Epkeret is applied in a conflict stemming from the murder of a particular member of the clan conducted by members of another clan. If the death of this clan member is responded by applying the lex talionis principle, what will happen is that the victim's clan will most likely seek retaliation by claiming the life of the perpetrator as required by the retributive principle. However, unlike the lex talionis principle, the retributive element in epkeret practice is not particularly prominent because epkeret is unintended to impose adequate suffering on the perpetrator of the murder. In many traditional societies, when a murder ( $f a h$ rahat) occurred, the chances of a violent cycle of vengeance to take place become wide open.

Among societies where the version of justice broadly reflects lex talionis principle, the victim's family will tend to demand appropriate retribution. If it involves murder, what the victim's family will ask for is most likely the death of the perpetrator. Of course, this demand will not be too much of a problem if the family of the perpetrator then meet the demands of the victim's family. However, in the case that the offender's family is unwilling to hand over the perpetrator, this murder case might be unresolved, and probably will increase the chances of a more severe conflict to develop among the conflicting groups. Alternatively, the victim's family will act against the perpetrator unilaterally without communicating with the perpetrator's family. If this happens, the way for a violent cycle of vengeance between the two groups will also be exposed because the unilateral action will be considered inappropriate and will be the casus belli for further retaliatory action that may then be responded by another group with subsequent retaliation. Epkeret 
practice is considered relevant to prevent the violent cycle of vengeance from appearing among the clans when a murder occurs.

If a murder occurs among the people of Southern Buru, the customary settlement that is commonly pursued is the settlement through the taking of the customary oath (esmake) accompanied by the application of epkeret as a complementary 'sanction'. The settlement was conducted through an adat ceremony led by Matgugul, attended by heads of soa, kawasan, prominent traditional figures, government representatives, religious leaders, the head of the local police department, the local army officer and the citizens. During the customary court ceremony (saniri), the clan of the perpetrator will appoint a clan member of the same gender as the victim to be handed over to the victim's clan. The submission will be accompanied by an esmake (adat oath) pronounced by the victim's clan and the perpetrator's clan with the following formula:

"Opo geba ka sula djunae, fidi ka fahan lalen ka tuke prenta la moyang tu geba mtuan to la du jagak fuka na, du jagak kai wait e la du newe tu gosan tu muan modan. Slake na do kamba epkamak ka ngan tu moyang ro, kami emhane la fena porua geran pa, kam puna oto gebana daba puna Epkeret ngei ana fina tu anam hana na lat hai tu huma lolin na lat puna ganti nak roko hadi daba mate tu fahrahat. Opo tu moyang ro kami fena po rua geran pa kamhane na bam sane potai smake na do da puta mhewak nake newen tu enmate ha odok ke."

(Translation: "God the creator of this world, from Thy hand, thou have commanded the ancestors and the elders to guard the island and preserve the brotherhood and sisterhood relationship among us, so that we live well and not destroy one another. We are now calling on God and our ancestors to witness us taking the oath, on behalf of the twentyfour clans, to make a bond for this person who accepted the epkeret custom .... (the name of the person will be declared), to go into the household of the deceased victim of murder. God and ancestors, we the twenty-four clans swear that whoever ignores and acts against this oath, the spear will pierce his heart, the disease will make his life troubled, and death will continuously follow him.")

The oath itself, in fact, reflects the fundamental principles adopted by the community. First, there is an acknowledgement that there is a supranatural authority ("the creator of the world") who gives directives on how the clans should live as brothers and sisters. This part of the oath is important since it reminds all the clans that the importance of preserving unity and familial ties is a supranatural order that should be obeyed. Second, the next part of the oath explicitly declares that a person from a family is transferred into the household of another family as an effort to preserve the relationship as commanded by the supranatural authority. Third, the existence of all clans is acknowledged, and all of them is implicitly required to oversee the implementation of epkeret. Fourth, there is also a threatening phrase in the oath, to emphasize the notion that the oath should be taken seriously by all members of the community.

After the adat oath is pronounced, the oath will bind all the members of the native clans. Furthermore, the person "established" by the perpetrator's clan will then be brought into the household of the murdered victims, and the problem is customarily considered to be resolved. Generally, the appointment of an "established" person would typically follow the qualification of the murdered person in terms of age and gender. However, there is a space for the families involved to negotiate the alternative condition.

The "established" person will then live his/ her life with his/her new family, and his/her new family will treat him/her as a member of their own family. His/her original family name will consequently be changed later according to his/her new family name. This stage is also called by the term "change of clan" or kalileit. Substitution of the family name is conducted at the same time in the traditional ceremony (saniri) and marked with the pronunciation of the following statement:

“Opo Geda Snulat Langina Dawa Lale Na, 
aleli ngat Nuru Dawa Na Soa da sisa la Soa tu ba umur salamat."

(Translation: "God the creator, bless me, I change the family name of this child and bring him/her to enter the new family. God bless him/her and give a long life.")

In this research, two murder cases were assessed to find out how epkeret is implemented. Furthermore, the two cases will be referred to as "the case of Simon Lesnusa" and "the case of Remi Solissa".

In the case of Simon Lesnusa, the perpetrator of murder (fah rahat) was Simon Lesnusa of the Lesnusa Clan, who took the life of a man named Philipus Liligoli of the Liligoli Clan, on Saturday, October 18, 1982, in Leksula village, which is now a part of South Buru Regency. The fah rahat occurred following a quarrel between Philipus Liligoli and the parent of Simon Lesnusa over the purchase of chicken in the local market. The quarrel got worse to the point that Philipus Liligoli beat Simon's parent. What was done by Philipus Liligoli was unacceptable to Simon Lesnusa, who subsequently defended his parent and involved in a brawl with Philipus Liligoli which caused the death of Philipus Liligoli.

Soon after the murder, the family of Lesnusa and Liligoli promptly held a meeting and asked the Matgugul to facilitate the process. During the meeting, the Lesnusas offered their land to compensate for the loss of the victim's family. However, the Liligolis insisted that they wanted the imposition of epkeret, in which the perpetrator's clan had to establish one of their members to replace the victim. There were two main reasons as to why the Liligolis prefer epkeret instead of rahe $n e f u$. First, they argue that it has been the traditional normative dictate that epkeret should be prioritized to ensure the restoration of broken ties between the families. Second, they perceive that there was a qualified person that may be appointed as the replacement for the murdered one. The deliberation then confirmed that the compensation in the form of land could only be accepted if there was no one in the perpetrator's family with the same gender as the victim who could be "established" as a substitute. As indicated above, gender and age are the common qualifications considered in epkeret. However, there was still space for the families to negotiate different or additional qualification. It means that if agreed by both sides, a man may be appointed as the replacement for a murdered woman and vice versa.

After being discussed internally, the perpetrator's family finally agreed to "establish" a member of his family to replace the victim. The family member who was "established" for the epkeret was Samuel Lesnusa, 12 years old at that time, the younger brother of the perpetrator. He was not as old as the victim of murder in this case, but based on the negotiation of the families involved, this age difference was acceptable. In a traditional ceremony, Samuel Lesnusa was later handed over by the chief of the Lesnusa Clan to the Liligoli Clan. Consequently, the name of Samuel Lesnusa was changed to Samuel Liligoli, according to the family name of his new family.

Although settlement had reached by implementing epkeret, criminal law enforcement under the national criminal law still also continued. As the murderer, Simon Lesnusa was later convicted by the Namlea District Court with two years imprisonment. From the perpetrator's point of view, when the imprisonment period finally over, he found it easier to continue his life without being worried about the possibility of retaliation by the victim's family to him or his family. He could freely meet and greet anyone, including the family members of the victim, who assume that there is no problem anymore between the Lesnusas and Liligolis. ${ }^{8}$

In conformity with the provisions of epkeret, Samuel Lesnusa who became an "established" person, then be brought into the victim's family and his family name was changed to Liligoli. After 
entering the Liligoli Clan, Samuel Liligoli has been well-treated, all his needs were fulfilled, and he is also considered as his "adoptive" parents' own child. His "adoptive" parent sent him to school properly until he finished his high school. He was then asked to manage the farmland owned by the Liligolis. This went on until he became an adult, getting married, and has two children. In terms of inheritance, he was treated like his "adoptive" kin. In brief, he lives his life as if he were the biological member of the Liligolis. However, familial relationship with his biological parents and their family also continues well. When his biological parents died, Samuel Liligoli and his adoptive parents also attended the funeral. ${ }^{9}$

In the case of Remi Solissa, fah rahat incident involving Remi Solissa occurred on Tuesday, February 17, 2015, around 08.00 PM in Siwatlahin Village, Fena Fafan District. This incident arose from an internal family quarrel between Remi Solissa of the Solissa Clan and his wife Yoneng Nurlatu of the Nurlatu Clan because Remi Solissa accused her of having an affair with another man. Starting from the quarrel, Remi Solissa then went uncontrollably mad, indiscriminately assaulted anyone around and caused four people dead and five others injured. The four victims who died were his wife, Yoneng Nurlatu (female, 27 years old), Herman Solissa (male, 16 years old), Yati Nacikit (14 years old) and Yoknan Solissa (male, 15 years old).$^{10}$ After carrying out murder and assault, Remi Solissa fled to the forest before being arrested by the police and convicted at the Ambon District Court, in which Remi Solissa was sentenced to life imprisonment.

Apart from the criminal law enforcement under the existing national law, the perpetrator's family and the families of the victims also seek a settlement through customary law institutions. Both sides agreed to apply epkeret to resolve the fah rahat incident, and the victim's family requested that the perpetrator's family "establish" substitutes for the victims. They agreed on the implementation of epkeret since there was a murder case with multiple victims. This was regarded as particularly serious and posed a greater possibility to badly damaging the relationship among the families. Thus, epkeret was deemed to be the appropriate way to handle this perilous situation. The adat session was held on March 17, 2015, in Leksula Village, Leksula District, led by Matgugul with the heads of clans, elders and regional leaders. Unfortunately, the researcher could only assess the settlement of the murder of Yoneng Nurlatu as the victim.

In the case of Remi Solissa, as far as Yoneng Nurlatu was the victim, the person who was "established" by the perpetrator's family to replace the victim (Yoneng Nurlatu) was a teenage girl named Martenci Solissa (16 years old). There was an interesting consideration developed during the discussion between the two families, which led to the appointment of Martenci Solissa. The crime carried out by Remi Solissa was considered extremely serious, so that the families agreed that the epkeret should be realized as soon as possible to prevent unwanted effects following the murder. Although there was a difference concerning the age of the victim, Yoneng Nurlatu, and Martenci Solissa, the parties decided to set aside this matter to advance the implementation of epkeret. Just as in the case of Simon Lesnusa, as the person "established" in the epkeret, Martenci Solissa also had to undergo the "changing of clan" (kali-leit) process so that her family name was changed to Nurlatu. According to Martenci, when she started living among the Nurlatus, she was somehow afraid. However, after a few months, she felt that her new family gave a sincere affection so that she gradually felt more comfortable.

\footnotetext{
Interview with Samuel Liligoli, the person appointed as the replacement for the victim in the murder of Philipus Liligoli, on December 26, 2016, in Leksula Village, Leksula District.

10 The victims' clans are indicated by their respective family names.
} 
In addition to Yoneng Nurlatu, another victim murdered by Remi Solissa was Yati Nacikit. The Nacikit family also demanded the application of epkeret in which the perpetrator's family appointed a member of the family to be "established" as a substitute for Yati Nacikit. Based on the deliberation, it was agreed that the "established" person who served as the substitute was a nine-year-old girl named Ribka Solissa. She was appointed to be the replacement for the deceased Yati Nacikit since both are female and their age was the same. Although the appointment of Ribka Solissa as a substitute in the epkeret was certainly a difficult decision for her family, interestingly the family was not too worried because they believe that their child will be treated well among her new Nacikit family. ${ }^{11}$

1. Contribution Epkeret to the restoration of relationship between the family of the victim and that of the perpetrator following a murder caseas a mechanism to break the cycle of violence after the murder cases in Southern Buru

Like any other societies, one of the basic needs of Southern Buru people is the continuity of existence and preservation of order. In reality, the sustainability of the existence and maintenance of order of a particular society can be threatened by both external as well as internal factors. In this context, one of the potentially destructive internal factors is the incident of murder, especially the one that involving two different clans in society. In traditional societies whose kinship is still close, murders involving different clans, although starting from individual interests, could create inter-clan conflict. The attachment of the perpetrator and the victim to their respective clan will, in turn, lead to strong solidarity development on both sides, which if not properly managed can result in the escalation of the conflict. When this developed solidarity exists in two parties with an increasingly intense conflictual relationship, it is possible that collective violence will manifest. In a group with a strong solidarity, an assault directed at one member of the clan will most likely be considered as an assault directed to the clan as a whole. Thus, the interpersonal conflict could easily develop into an inter-group feud with a greater possibility of involving group violence. For instance, the triggering incident (casus belli) preceding intergroup conflict in Sampit, Kalimantan, in 2001, was a personal quarrel between persons belonged to different ethnic groups, in this case, the Dayaks and Madureses. At this point, threats to public order, or even to the sustainability of the existence of society, will be under real threat.

The potential threat to public order and the existence of the society will be greater if a society is dominated by the idea of lex talionis as their core value of retributive justice. If retributive justice becomes the dominant version of justice in society, the 'damage' inflicted in a murder case must be counterbalanced by the imposition of equal 'damage' to the other party, i.e. by taking the life of the murderer. There are times when this retributive mechanism could solve the problem. However, there is also a great possibility for the emergence of the cycle of violence as a result of conflicting parties' uncontrollable reciprocal actions.

In the modern state context, efforts to prevent the cycle of violence are done by introducing a formal institution called the court. With authority derived from the state power, the courts assume the role of deciding and resolving disputes or conflicts among community members. It is erroneously assumed that when the court has reached the final decision, whatever it may be, the parties to the dispute will accept it and the conflict is settled. Thus, unilateral actions outside the court settlement framework are not expected to occur.

Nevertheless, the assumption is not always true. Dispute settlement through a formal mechanism in the courts does not necessarily guarantee that a

11 Interview with Ibu Koce Solissa, the biological mother of Ribka Solissa, the girl who was "established" as the replacement of the murder victim, Yati Nacikit. The interview was held on January 2, 2017, in Siwatlahin Village, District of Fena Fafan. 
dispute or conflict could be resolved thoroughly. Formally, a dispute may be deemed to have been resolved once the examining judge strikes the court gavel to proclaim that the decision over a dispute has been delivered. However, from a sociological point of view, there is always a possibility that the dispute is far from being considered as completely resolved, and opportunities for a prolonged dispute are still exist. If that happens, regrettably, the judiciary does not play a substantial role as a true dispute resolver.

For the people of Southern Buru, security, order and sustainability of existence are regarded as priorities. Therefore, the development and maintenance of substantial and thorough dispute resolution mechanism are also viewed as a very important necessity, and epkeret can be seen as the manifestation of this mindset. From the two cases discussed, it is obvious that even if the national criminal law enforcement mechanism is applied, the community also applies their own conflict resolution mechanism in the form of epkeret practice simultaneously. This phenomenon indicates that justice brought by the enforcement of the national criminal law is not necessarily expected to bring settlement that fit the need of the people. As stated by Oldenquist, judicial retribution involving the court is basically 'sanitized' revenge administered by police and judges who are not the criminal's victim or relatives. ${ }^{12}$ In such situation, there is a possibility that the community's version of an ideal settlement is different from the version of the justice officers.

In addition to being part of a tradition that has been applied since a long time ago, the application of epkeret along with the national criminal law enforcement through formal courts also shows that national law enforcement does not necessarily solve the problem completely once and for all.

By applying their local wisdom, the people of Southern Buru created a communal mechanism to control murder incidents that are seen as potentially capable of triggering a cycle of vengeance between the families of the victim and the perpetrator. Through the implementation of epkeret, theinter-clan problem is ingeniously transformed into a problem that falls under the realm of the extended family of clans that are closely tied by kinship. Within such a kinship framework, both the perpetrator of a murder and the victim are considered as parts of a single larger family of clans. Therefore, the application of retaliation based on the principle of lex talionis is considered as an inappropriate act of self-injuring.

This notion is well presented by McCullough who studied the evolution of forgiveness instinct in a human being. McCullough argues that humans are known to retaliate against their blood relatives, on occasion quite harshly. However, it is relatively rare for human beings to use blood revenge against their own kin. He explained that filial bonds, gratitude, mutual dependency, and brotherly love help to restrain vengeance against loved ones. Further, McCullough also stipulates that harsh revenge against a blood relative, insofar as it reduces the relative's fitness, reduces the avenger's fitness as well. ${ }^{13}$ If applied on epkeret, McCullough's theory is appropriate. It is true that in epkeret the one sent a family as the replacement for a murder victim does not have any biological relationship whatsoever with the family. However, it is interesting to find out that epkeret is a way to create artificial yet strong family ties among the person appointed as the replacement, his/her biological family and the family of the victim. Once this familial tie is declared and strengthened through epkeret, McCullough theory on non-revenge of relatives becomes relevant. As Boege puts it, the punishment of the perpetrators of disapproved conduct will likely be viewed as harming the group for the second time. On the contrary, it is preferable to re-establishing harmony and reintegrating the deviant members. ${ }^{14}$

However, since murder is a criminal act

\footnotetext{
Charles K.B. Barton, Getting Even - Revenge as a Form of Justice, Open Court Publishing, Chicago, 1999, p. 54.

Michael E. McCullough, Beyond Revenge - The Evolution of the Forgiveness Instinct, Jossey Bass, San Fransisco, 2008, p. 89.

Volker Boege, "Traditional Approaches to Conflict Transformation - Potentials and Limits", paper, Berghof Research Center for Constructive Conflict Management, Berlin, s.d., p. 7.
} 
under the criminal jurisdiction of the state courts, the criminal law enforcement process against the perpetrators of murder is still respected by all parties in accordance with applicable laws and regulations. Nevertheless, when epkeret has been implemented, the potential for the emergence of subsequent communal conflicts as a result of the murderous action is less likely happen at the time of the defendant's examination and even after the perpetrator has served the court sentence. At this point, it must be acknowledged that the epkeret tradition has substantially capable of breaking the cycle of vengeance that may not be totally removed by the court decision. From this point of view, epkeret deserves to be maintained as a method based on local wisdom that supports the realization of security, peace and public order. It is an important social capital that must be seriously considered in criminal law enforcement.

It should always be recognized that the ultimate goals of law are the realization of security, peace and order in any given society. Therefore, when the epkeret practice is proven to be capable of realizing the security, peace and order of the society after the disturbing murder incident, criminal law enforcement must also be carried out in such a way that the security, peace and public order are maintained. A concrete step that can be taken by the court in examining and deciding murder case in which epkeret is applied simultaneously is to wisely assess the "reconciliation" through epkeret as a factor to alleviate the criminal sanction as much as possible. Unfortunately, while the court decision in the case of Simon Lesnusa is inaccessible, the court decision in Remi Solissa case did not mention about the amicable conflict settlement process as reflected in the epkeret. Remi Solissa was prosecuted in the District Court of Ambon under the case registered by the number 174/Pid.B/2015/PN.Amb. This court is located on a different island, more than 100 kilometers away from the locus delicti. Therefore, there was no intense flow of information between the community who sought an amicable settlement to prevent retaliation following the murder case, and the formal criminal law system institutions examining the case. Moreover, the extremely brutal nature of the multiple murder seemed to seize the attention of the court, so that extra court dynamics was overlooked.

In the future, perhaps these two tracks in settling a particular conflict in different systems, which are the formal judicial and informal settlement, should be somehow integrated to achieve not just a formally justified settlement but also socially accepted resolution. The study conducted by Novri Susan et al. also suggest that adat institution should be given proper space in efforts to settle social conflicts. ${ }^{15}$

\section{Perception of the people who are directly affected by the implementation of epkeret tradition and its effectiveness}

This research reveals that even though epkeret tradition has been established for quite a long time ago, people tend to view this adat institution in a positive way. Regardless of the change in social structure due to modernization, the natives of the Southern Buru Island basically perceive epkeret as a suitable institution which is still needed to guarantee peace and order at times when the community's cohesiveness was at stake following fah rahat (murder) case. This could be well inferred from the two cases studied, which shows that the concerned families promptly encouraged communication between themselves to avoid further violations that may develop in such a way beyond the control of the community. The existence of adat structure and the well preserved traditional dispute settlement mechanism, particularly the one that involves epkeret, verify the fact that epkeret is still relevant among the Southern Buru island nowadays.

From the perpetrator's point of view, epkeret does not only serve as a means to ease the tension

15 Novri Susan, et al., Peran Pranata Adat dalam Pencegahan/Penghentian Konflik antara Kelompok Masyarakat, Badan Pembinaan Hukum Nasional, 2014op.cit., p. 44. 
between families following a murder case, but also works as a vehicle to reintegrate with the society without being haunted by the possibility of vengeance. This is apparent in the case of Simon Lesnusa, who, after serving two years in jail for the murder of Philipus Liligoli, could well reintegrate with the community. In terms of contemporary penal policy in criminal law, reintegration of perpetrators of crime into the society is an important objective. However, even after a perpetrator of a crime serves his/her punishment in jail, reintegration has sometimes posed a problem that could not be overcome easily. The presence of an ex-criminal among the society could bring the people's memory back to the time when the crime took place. The worse situation may also accompany when the family of the victim attempt to make the murderer pay the debt based on the lex talionis principle. It is clear that epkeret has played an important role in relieving the psychological burden of the perpetrator as well as the family of a murder victim to help them move away from the dark chapter in their past toward the restored future relationships.

This positive perception is also shared by the family of the victim of the murder case. It is true that nothing could bring the victim back alive. However, epkeret has provided a sense of satisfaction among the victim's family, because they lost one of their beloved members, but later they welcomed a new family member. In addition, the person who was appointed to stand as the "replacement" will likely strengthen the ties between the family of the perpetrator and that of the victim since that person would subsequently have strong attachment both to his/her biological family and his/her adoptive family. Briefly, the satisfaction was developed among the family of the victim because, in a way or another, there is a compensatory nature in epkeret, although this is not necessarily linked to material aspects. As for the family of the perpetrator, epkeret is satisfying because they are ensured that further retaliation from the family of the victim would not happen. Moreover, their relationship with the family member who was transferred to the family of the victim will most likely be maintained.

As for the perception of the perpetrator's family, the case of Remi Solissa provided an important point of view. In epkeret practice, the perpetrator's family must provide a member of their family to become the replacement for the murder victim. The information gained from this research clearly demonstrates that the decision to appoint a family member to be transferred to the victim's family as the replacement for the victim was hard to make. However, epkeret practice has strengthened their confidence that their family member who was transferred to his/her new family would be welltreated and would not be abused. This confidence was improved since epkeret is a well-accepted practice among the community, and its performance was monitored by other clans and the prominent figures in the society. To some degree, although it has not been an easy choice, the perpetrator's family could rationalize that epkeret is the best way possible to prevent their family members from being murdered in actions driven by vengeance.

The perception of the replacement was represented by Samuel Liligoli (previously Samuel Lesnusa), who was transferred to the Liligoli family following fah rahat (murder) case conducted by his brother, Simon Lesnusa, which took the life of Philipus Liligoli. At first, he experienced fear and uneasiness. However, subsequently, as he knew that he was welcomed and accepted as a member of his new family, he started to develop more positive feelings. He started to mingle with his new family members as well as the members of the extended family and adjusting to the lifestyle of his new family. It is worth mentioning that the fact that epkeret although involving the change of family name of the replacement - did not necessarily ruin the biological and social relationship of the replacement with his/ her former family. This situation has significantly encouraged the development of constructive feeling on the part of the person who was appointed as the replacement to continue his/her life in a new situation in the new family.

To sum up, people who are affected by the 
implementation of epkeret tend to perceive epkeret in a positive sense. Epkeret is regarded as a positive practice because it can ease the tension between the families after the murder case, and thus, works well as a vehicle to reintegrate the society. From the perspective of the victim's family, epkeret has provided a sense of satisfaction because their loss of their beloved one is compensated. Epkeret also strengthens the ties between the family of the perpetrator of the murder and that of the victim. Although their relationship was disrupted by the murder case, their future relationship will not likely damaged.

From the side of the perpetrator's family, the implementation of epkeret has encouraged their belief that further retaliation from the family of the victim would not happen. Since the performance of epkeret is backed by adat institution and monitored by adat figures, the perpetrator's family will be confident that their family member who was transferred to his/her new family would be welltreated and would not be abused. The involvement of adat institution and prominent figures in the implementation of epkeret has enhanced the reliability of the practice, and thus, enable epkeret to play an optimal role in conflict resolution. This finding confirms the notion stated by Novri Susan et al., that conflict resolution will be optimal if adat institutions are actively involved in settlement measures. ${ }^{16}$ Furthermore, for the perpetrator's family, epkeret is also the best way possible to prevent their family members from being murdered in actions driven by vengeance.

In the implementation of epkeret, the person who is harmed the most is perhaps the one who is appointed as the replacement for the murder victim. There is a reasonable fear that his/her relationship with his/her biological family will be cut-off. However, this research shows that the person appointed as the replacement held a positive view on epkeret since epkeret did not necessarily ruin his/ her biological and social relationship with his/her original family.

The positive view toward epkeret has supposedly contributed to the effectiveness of epkeret as a traditional institution that plays an important role in preventing the possibility of violence-cycle to take place. Based on the information gathered, it is apparent that the murder cases did not develop into a violent cycle of vengeance. Instead, the cases are well settled by the implementation of epkeret, which is perceived positively by all related parties. It indicates that epkeret is an acceptable practice that is effective to settle conflict arising from murder cases.

\section{Conclusion}

The practice of epkeret is a significant example to show that the traditional community of Southern Buru, with their local wisdom, has developed epkeret as an effective mechanism to restore their condition following the occurrence of a disturbing murder incident that may lead to further widespread conflict and could trap groups into an endless cycle of violence.

As for the first research question, this research found that epkeret plays an important role in restoring the relationship between the family of the victim and that of the perpetrator following a murder case. Epkeret breaks the cycle of violence by The relationship was restored when epkeret reconnectinged the seemingly disturbed familial ties between the families of the perpetrator and that of the victim. The reconnection of families and restoration of familial ties significantly contributed to the prevention of a cycle of violence from emerging. The success of epkeret to break the cycle of violence is influenced by the close family ties between the clans of South Buru and respect for the traditional customary institutions.

Concerning the second question, this research found that basically, people who are involved in the implementation of epkeret tradition following the murder cases have positive perception 
regarding the epkeret practice. The persons sent to the victim's family as the replacement gradually developed a confident attitude toward his/her position as a new member of the new family. This positive attitude was encouraged by the receptive behavior on the part of his/her new family. Another factor that contributes to the development of positive perception, particularly on the part of the perpetrator's family was the confidence, which is normatively true, that biological relationship was not entirely broken between the family and the person appointed as a replacement. The positive view embraced by all parties involved in epkeret practice basically contributes to the effectiveness of epkeret in two cases examined.

The intimate familial ties among the people of Southern Buru make them feel that in the end, both the victim and the perpetrator of the murder are still bound by fraternal ties. Thus, taking revenge by killing the murderer is considered an act of selfhurting, and it should not be done. Strong kinship is also supported by a second factor, which is respect for the customary institutions represented by traditional elders and ceremony. Oaths held by this traditional people are considered to contain a substantial degree of spiritual authority so that when the esmake and epkeret are realized, the parties concerned will most likely honor its implementation.

This research also reveals that, although epkeret is an old tradition, it still has relevance until now. The features of epkeret have encouraged members of the community of Southern Buru to develop a positive perception of this practice, and thus, guarantee its existence and relevance.

\section{REFERENCES}

\section{Books}

Barton, Charles K.B., 1999, Getting Even - Revenge as a Form of Justice, Open Court Publishing, Chicago.

Leeuw, Frans L. \& Schmeets, Hans, 2016, Empirical Legal Research A Guidance Book for Lawyers, Legislators and Regulators, Edward Elgar Publishing, Cheltenham.

McCullough, Michael E., 2008, Beyond Revenge - The Evolution of the Forgiveness Instinct, Jossey Bass, San Fransisco.

Putnam, Robert D., 2000, Bowling Alone, Simon \& Schuster, New York.

Susan, Novri, et al., 2014, Peran Pranata Adat dalam Pencegahan/Penghentian Konflik antara Kelompok Masyarakat, Badan Pembinaan Hukum Nasional, Jakarta.

\section{Journal Articles}

Faqir, Raed S.A., The Philosophy of Punishment: A Study to the History of Classical and Positive Schools of Penology, Forensic Research \& Criminology International Journal, Vol. 1
Issue 6, 2015.

McBain, Graham, Modernising the Law of Murder and Manslaughter, Journal of Politics and Law; Vol. 8, No. 4, 2015.

Mengesha, Abebe Demewoz et al., "Indigenous Conflict Resolution Mechanisms among the Kembata Society", American Journal of Educational Research, Vol. 3, No. 2. 2015.

\section{Paper/Research Reports}

Boege, Volker, "Traditional Approaches to Conflict Transformation - Potentials and Limits", paper, Berghof Research Center for Constructive Conflict Management, Berlin.

Susan, Novri, et al., 2014, Peran Pranata Adat dalam Pencegahan/Penghentian Konflik antara Kelompok Masyarakat, Badan Pembinaan Hukum Nasional, Jakarta.

\section{Court Ruling}

Ambon District Court, Case Number: 174/ Pid.B/2015/PN.Amb 